\title{
Crito: Upon the Duty, Citizenship and, Justice
}

\section{Kriton: Ödeve, Doğruluğa ve Yurttașlı̆̆a Dair}

\author{
DEVRİM ÖZKAN (D \\ İzmir Katip Çelebi University
}

Received: 21.09.20I8 | Accepted: I8.12.2018

\begin{abstract}
This study analyses Plato's work Crito with the rhetoric analysis method. Plato's work Crito is one of his most important works of political philosophy. In this work, Plato develops the key qualities of his own political philosophy. Inspired by the fact that Socrates does not escape the capital punishment, he is sentenced in order not to undermine the ethical principles to which he always adheres, Plato handles duty, citizenship and justice concepts. Thus, he develops his philosophical understanding of what qualifications a "polis" or a citizen should have. Considering Plato's influence and decisiveness on all history of philosophy, Crito needs to be re-analyzed with new analysis methods. In this context, considering that Plato created his works in order to establish a state that he idealized, Crito needs to be analyzed with rhetoric analysis method which handles the analyzed subject based on the purpose of the author.
\end{abstract} Keywords: Crito, polis, duty, citizenship, justice.

(C) Özkan, D. (2019). Crito: Upon the Duty, Citizenship and, Justice. Beytulhikme An International fournal of Philosophy, 9 (I), 89-IOI. 


\section{Introduction}

This study analyses Crito, which is one of the canon works of political philosophy. Focusing on how the most ideal polis and citizen should be, Plato developed political philosophy. Thus, unlike Aristotle, the works of Plato deal with how a state should be, rather than what the state needs to be, while the analysis in the works considers the aim of the author. Therefore, the rhetoric analysis method can be used as a tailored tool for analysing Crito, because Plato believes that the factual reality is completely fake. To him, reality is beyond the phenomenal world that is visible to the eyes of people, and one can conceive reality only through the dialectic method. Plato develops his world after seeing the reality regarding "how the state and citizens should be" by thinking and making use of the dialectic method. The main issue of Crito pertains to how the state and citizens should be, rather than what they are. Thus, analysing Crito with the rhetoric analysis method in this article will show what influence the purposes of the author have on shaping the main elements in the text.

Plato was a witness of the Peloponnesian War (43I-404 BC), which was one of the most important civilisation crises to have ever been seen throughout human history. Faced with huge social, political and economic crises because of this war, Athenians rethought many issues regarding the purpose of human beings and their place in society, especially with regard to justice and merit. Like his master (Socrates), Plato decided to become involved in philosophy so as to bring society goodness and truth. His belief that the goodness and regime can be re-established by means of becoming involved with philosophy is very effective, because Plato handles the state as a project to be created (Huard, 2007: 54). Therefore, the main guides are the ideas in Plato's books regarding how the state that he plans to establish - should be. Thus, the questions about how and by whom the state should be ruled are at the centre of Plato's political philosophy (Rep. 327a-62Id). However, the issue of how citizens in polis should live, including those who came together as a result of a political alliance, is also a very important one. Handling the issue of what the duties of citizens against the polis and what they can contribute to the polis with the sense of loyalty clarifies the main features of citizenship. In this 
sense, the main problems of political philosophy are taken care of in Crito by handling the citizenship concept within the duty and relevant concepts. Plato aims to establish the foundation for developing political philosophy so as to achieve an ideal state. Therefore, rhetoric analysis, which separates various elements in the text and sets up a combination between them in a qualified way (Logan, I978: 62I), needs to be used in an effective way in order to analyse Crito.

\section{Tradition and Philosophy in Crito}

For rhetorical analysis, what the author aims to acquire by means of the text he creates is very important. Therefore, of vital significance is how the historical conditions and needs during the time of the author, as well as the form of the text, would affect the persuasion period. From this perspective, it should be kept in mind that the Peloponnesian War, which was the largest crisis in Greek culture, had various influences on Plato's work. The social and political consequences of the Peloponnesian War are the most important reasons why Plato's works - as a means of education - differ grammatically from the works of Homer and Hesiod. It is immediately noticed that Plato's works are representative of a new tradition and a new start, unlike the poem-based archaic religious education. While Homer and Hesiod tell stories through poems, Plato prefers to persuade and explain through discussion, dialectics, questions and answers. Even this variation of explanation method is an indication of divergence regarding what kind of citizens Homer and Hesiod want to educate. Indeed, they aim to create enthusiasm among the audience by addressing their souls, passions, desires and aspirations. The poem's audience learn what kind of life is desired and should be lived, while they also lose themselves in the heroism stories. The values made up for generations are given in the lines written by Homer and Hesiod. These values create guidance about what a good citizen should do. However, Plato's

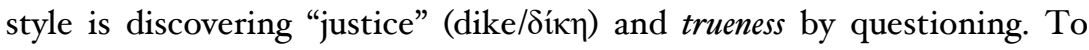
him, trueness exists regardless of time, place and culture. What a person should do is discover the trueness by questioning after achieving, so as to get rid of all illusions which can misguide him. Traditions, cultures, beliefs, habits and passions are factors which steer a person off the path to trueness. Obtaining correct knowledge is the main activity which leads us 
to the trueness. Life cannot continue in an ideal way with the habits inherited from the past generations. Trueness must be learned in order for life, city and state to become more qualified. For this reason, everything we have learned so far should be questioned. Accepting and maintaining the already "existing" things is not something which should be done by an ideal citizen. Creating dialogue and asking questions to formulate a "synthesis" in order to learn what "the right thing" is, is the "dialectic" method which should be used for learning the trueness. In this way, not only are citizens sure to have an ideal education, but the state is also sure to become more qualified.

In his work Crito $^{\mathrm{I}}$, Plato leads the way for Athenians to become involved with the thinking process by making Socrates and Crito have a dialogue with regard to the duty and belonging concepts in order to discuss how a citizen should be. Indeed, the basic motivation of Plato's dialectic method is a strong faith whereby one can reach the trueness not by being enslaved by his excitement, passion and ambition, but by thinking, researching and questioning. This method requires the suppression of humanitarian characteristics such as excitement, passion and ambition, but enlightened thinking and questioning. One is inclined to be fascinated with poetic feelings in order to gain the admiration of others or be effective. Thinking and questioning are the only things preventing one from being fascinated with such feelings and becoming involved in harmful activities against him and his city. Therefore, Plato tried to teach the dialectic method to his readers by using a discussion- and dialogue-based style in his works to handle some issues.

In Crito, although Socrates is faced with such a tragic condition as "being sentenced to death", he handles the issue by not taking it personally. He searches for what is the right thing to do instead of acting in a way that would serve his interest by showing various reasons, which is something wrong to do. Things need to be overviewed so that they are

\footnotetext{
Although the Apology of Socrates was written by Plato, it should be accepted as a work by Socrates. On the contrary, it is more reasonable to accept "Crito" as a common work of Socrates and Plato because, although it is based on an event which was identified by Socrates, it includes the opinions which constitute the cornerstones of Plato's works "Republic" and "Laws". Therefore, it is appropriate to consider "Crito" as a bridge where the opinions which matured in "Republic" and "Laws" newly sprout.
} 
searched and analysed in the right way. Therefore, the correct method is to ask questions and seek answers. Most of the time, the beliefs which encircle people prevent them from learning what the right thing is. What is thought to be the correct knowledge about subjects and phenomena may not really be the correct knowledge. Getting rid of the imaginary element should be the first step to take, not only for searching the knowledge about natural things, but especially the knowledge concerning political and ethical phenomena. Priority is also an important issue in this context. Many issues and phenomena to which society attaches importance may actually be unimportant and valueless. What is deemed important by the philosopher and what is known as important may differ. Undoubtedly, the members of every society need many beliefs and a great deal of knowledge to create functional coordination and partnership. Society becomes functional thanks to these beliefs and knowledge. Many qualifications which constitute a society occur thanks to beliefs and knowledge. A philosopher questions whether these things are adequate, valuable, right and important. However, a poet tries to guide new generations by praising the beliefs and knowledge of the society, which arise because of their strong faith. While a philosopher leads society to trueness, a poet tries to maintain the traditions. The main principles, beliefs and knowledge needed to gain and maintain sociality may not be appreciated or may be rejected by some. A philosopher provides alternatives to these principles, beliefs and knowledge. Proposing a system for establishing a more ideal life, philosophers gain their power and legitimacy from the correct knowledge and reason. Although an ordinary citizen contents himself with the beliefs and traditions handed down to him because he is loyal to the political system, a philosopher questions all of them through reason. Therefore, while all citizens would escape the "death penalty" without consideration if they had the opportunity, Socrates prefers to assess the issue by adopting the principle of "bow an ideal citizen act", and to make his decision accordingly.

\section{Citizenship and Belonging: Between Right and Wrong}

Of importance for rhetoric analysis is not only the method applied by the author to persuade the reader, but also what he aims to achieve via this persuasion. Plato tries to persuade his readers, making use of the 
literal pleasure and instructiveness he gains during the progression of dialectic thinking. Throughout the text, he tries to persuade his readers that laws should be valued above everything in order to sustain the social and political life. For this purpose, Plato presents the philosopher (Socrates) with rational knowledge which goes against the beliefs which society has accepted and not questioned (Russell, 2005: IO). Moreover, Plato also reaches the knowledge about how citizens should behave in the city, through thinking rationally. The main issues in Crito are the nature of the duties of citizens, and what is crucial for the social life which makes them feel that they belong to their city. In this context, the main problems of political philosophy are given in Crito by handling the concept of citizenship within the context of duties and belonging senses. In this way, Plato aims to establish the basis for the political philosophy for establishing an ideal state. Since the traditional beliefs about citizenship fail to fulfil the requirements for an ideal life and establishment of the city, the philosopher wants to replace them with correct knowledge. Belief cannot be the source of knowledge for philosophy. For the philosopher, relational knowledge is the only alternative to the handed down beliefs. "What should be" cannot be established as long as opinions are not replaced with knowledge and beliefs are not replaced with reason. Therefore, political philosophy is a stranger to traditional belief and comprehensions. Acting according to the principles of thinking right in order to reach the knowledge which is valid everywhere and every time, a philosopher needs to become a stranger to the beliefs and habits of his city. Although these beliefs and habits ensure a harmonious life, it is not possible for a philosopher to accept them when they are not right and rational. In this sense, in Crito, the philosopher is presented as someone who pursues trueness even if it claims his life, putting aside all values, beliefs and habits of the society.

Crito was bound to Socrates with love, loyalty and friendship. One of the prominent rich people in Athens, Crito formulates an escape plan for Socrates. Sentenced to death, the philosopher thinks that the situation he has encountered should be solved according to principles based on reason, trueness and real knowledge. Faced with death, Socrates tries to persuade Crito, who implores him to save his life, and that they should act 
as they are required to act, rather than considering the thoughts of the majority (at $\mathrm{Cr}$. 43a-54c). Crito thinks that Socrates is not accepting the escape plan because he feels that Athenians will damage his friends who will stay in the city. Crito tells Socrates that they should not be worried about such things and that he and his friends are ready to pay any price. After explaining to Crito that he is worried about certain other factors that are more important than those which he has explained, Socrates invites his friend to think about the situation they are faced with and what they need to do $(C r .46 \mathrm{~b})$. Therefore, the two friends have a dialogue which has come to be one of the fundamental texts of political philosophy.

In the dialogue, the themes are: Socrates "certainly needs to escape" (Cr. 46a), "his death will be a big loss for all of his friends, especially Crito" (Cr. 45e; 44b-44c), and "if he doesn't escape, people would think that Crito doesn't want to save him" (Cr. 46a; 44b-44c), "not escaping will mean that Socrates' enemies' wishes are fulfilled" (Cr. $45 \mathrm{~d})$. Based on these themes, Crito persuades Socrates to escape. However, the main basis of Crito's discourse which he develops to persuade Socrates is that "everyone who is sentenced death will try to escape". However, Socrates believes that the method applied by everybody will not be right every time. To him, his position, which is based on a political issue, needs to be assessed by a political expert using an adequate method, just like a person dealing with a physical education needs to rely on a physician and a trainer. This thought will lead to a comprehension of its own accord that the ideals of experts about policy, law and regime are more important ${ }^{2}$.

Insisting that Socrates should absolutely escape, Crito asserts that it is not only necessary but also obligatory from the ethical perspective. To him, if Socrates does not escape, he will cause his enemies to carry out horrible actions, and will therefore be an accomplice. Moreover, Socrates is told that he should escape in order to educate and bring up his children. Furthermore, Crito thinks that someone is doing nothing against his enemies if he is cowardice. As is seen, the thought and perceptions of

2 This understanding paved the way first for political philosophy and then for political science to be established as fields of study. 
others are more important for Crito. In actual fact, Crito expresses the Greek ethics. According to these ethics, a man must perfectly develop the abilities granted to him by the gods and do his best in terms of taking his share from life. However, Socrates advocates different ethics and political understanding.

First of all, Socrates thinks that making something wrong against some other things which is wrong is not right $(\mathrm{Cr} .49 \mathrm{c})$. The main problem for Socrates is whether the best for someone is different from the best for his city. In this way, the problem will not be individual but social. For Socrates, principles are always more important than the thoughts and behaviours of other people. Therefore, he insists on being bound to the knowledge and opinions which he has acquired previously by questioning. Although thinking and acting differently to protect his own interests seems to be more beneficial for him, his faith is not shattered. Therefore, he insists on believing that objecting to the laws and rules of Athens, where he was born and brought up, will not be good for him. Breaking the laws and rules will not only damage Athens, which essentially represents a political unity, but also the person who rejects the laws. If everyone declares that they do not recognise the laws when the laws are against their own interests, then the system (framework), which is an opportunity to live together, will not work. A non-working political system will not only make it impossible to live in unity, but will also make it impossible for individuals to have a private life and make use of the opportunities provided by the city. Every Athenian is owed many opportunities, such as education, health, trade and security, which ensure a private life according to the laws of the city. They could develop themselves thanks to the advantages provided by the laws. Therefore, if he does not obey a decision which is made regarding himself according to the laws, then Crito damages the system which provides him with his status. Likewise, all Athenians do not owe their citizenship only to their families, but also to Athens. Therefore, each citizen belongs to Athens. Athens and its citizens belong to one another. Their belonging to one another mutually is contracted through laws ${ }^{3}$. Violation of this contract endangers the existence of both

3 There are important differences between the conception of "contract", which is seen for the first time in Crito dialogue, and the "modern social contract theory". While Plato 
Athens and its citizens. No citizen has the right to risk his children's future by risking the existence of the city he belongs to. The continuation of the political system depends on citizens' acting with responsibility against the city and the city being responsible for its citizens. Citizens violating laws is the biggest irresponsibility against their city. In actual fact, a citizen who betrays the city (Athens) which "be belongs to" and which "belongs to him" is not a virtuous one.

Socrates thinks that he has various opportunities thanks to the city where all citizens continue their lives by being belonged to. In return, Athens also wants its citizens to contribute to the life-world which the citizens have created together. Any citizen who is tried has the right to defend himself. A virtuous citizen would not prefer to violate laws to persuade the other citizens during the trial process in order to make it possible for the laws to be enhanced. Moreover, automatically accepting that Athenian laws are ideal for him by not preferring to migrate to another city in his 70-year life means that Socrates accepts the punishment according to the laws $(C r .53 \mathrm{~b}-52 \mathrm{c})^{4}$. Making the laws, thanks to the existence and usefulness of which he has many advantages, non-functional is something wrong to do. Given that something which is wrong for somebody cannot be something right for another, something wrong for the city can also not be something right for the punished person. Therefore, imposing the punishment which is given according to the provisions of laws is good both for him and for the city.

\section{Private Life and Public Life: About Duty}

Determining the main concepts and ideas in the analysed text is required in order to carry out rhetoric analyses in a qualified manner. As asserted by Likhovski (I997: 205), the terms and concepts selected by the text author are not only a reflection of reality, but also shape the reality.

stresses citizens' "dependence" on the political system, modern social contract theories prioritise independent and rational individuals as well as the political system established with the coordinated actions of these individuals.

4 Another theme in Crito dialogue is that it is not possible for Socrates to go to another city after he is punished; just because a citizen shows that he believes that the laws of a city are good, living in that city for years does not mean that he will have a happy life due to the fact that he will be considered a person who has "violated the laws of a good city" (Cr. 53c). 
In this context, it is clear that the "majority", "wrong", "true", "lawe" and "state/city" concepts in Crito are determinantal. However, when Crito is analysed using the rhetoric analysis method, it is observed that all of these concepts are handled within the frame of a distinction between private life and public life. It is extremely striking that there is an absolute distinction between private life and public life both in Crito and The Apology of Socrates (Ap. I7a-42a) ${ }^{5}$. After explaining to the Athenians that he does not ever take care of political duties and partnership, Socrates also stresses that money and properties are not important things for him. He declares that instead of taking care of these, he endeavours to go to each of the Athenians (their private spheres) to make sure that they are fine ( $A p$. 36c). For Socrates, the achievements in the public life are not important, but a person discovering good and merit by questioning his private life is important. Therefore, Socrates asks Crito "why should we care so much about what the majority think?" $(\mathrm{Cr} .44 \mathrm{c})$. The thing which matters is the trueness which is discovered by someone through questioning based on the principles of reason and logic. The trueness of laws pertains to what is right and what is wrong, regardless of public opinion. A citizen should not be influenced by the traditions and habits of the majority when he decides on how to react to the laws. Otherwise, many people with conflicting interests would react to laws differently, thus making it impossible for public life to be sustained.

Asserting that Socrates deals with subjective issues rather than public issues, he presents his perspective on citizenship and belonging. According to Homer, citizenship is meaningful with patriotism. In the Ancient Greek Culture, becoming a citizen of a city requires showing faithfulness. Declaring that his field of interest is private life, Socrates asserts that he has a different comprehension of politics. Therefore, political and ethical justice and trueness are independent of the public opinion. A soothsayer in Delphoi says that he is the most learned man, when he enquires as to "what wisdom is" in the public, but does not have a satisfactory an-

\footnotetext{
5 Weiss (1998: 7) draws attention to the fact that there is a dramatic continuation between "Crito" and "The Apology of Socrates" dialogues. However, he also stresses the importance of whether Socrates figures out that the person who is loyal only to God in "The Apology of Socrates" is replaced with the "city's obedient son" in Crito.
} 
swer from anyone; as such, he decides that an objective thinking process is required in order to really learn something. Socrates mainly uses induction as a method, giving prominence to objectivity in order to make his subjective reasoning and questioning independent of any king of transition, authority and public prejudices. However, does Socrates have the right to disturb the public peace as a result of the reasons and knowledge he reaches through the questioning in his private life? This question refers to the difference between The Apology of Socrates and Crito. While Socrates challenges the laws, traditions, prejudices and habits of Athens in The Apology of Socrates, he judges himself more perfectly than those who accused him, in Crito. One should not damage the political system of a city no matter how right his subjective judgements are, and no matter whether he thinks that he has been treated unfairly. Therefore, regardless of how right a citizen is, violating the laws of a city will damage the system which makes it possible for citizens to maintain their lives, and therefore should not be done. However, every citizen should share the experiences and knowledge he receives in his private life with the public, so that the public life has an ideal structure. In other words, every citizen is obliged to enhance the city by persuading the other citizens that the knowledge he has acquired by questioning is right $(C r .52 a)$.

\section{Concluding Thoughts}

Aristotle begins his work Politics by making a comparison between how a householder rules his house and how a head of state rules a state (Pol. I.I252a). This compression is completely scientific. On the contrary, in Crito, Plato develops - as a project - a contrasting political system which is different from the system which can be referred to as the sacred kingdom or prophet king ${ }^{6}$ in the Middle East or Mesopotamia; indeed, it is also different from the Greek Democracy ${ }^{7}$. In a system in which kingdom and

6 The Akkadian Empire Naram-Sin, who ruled between 2254 BC and 2218 AC, was the first Mesopotamian ruler to define himself as a "sacred king". Kings often claimed that they were sacred after Shulgi, (2095-2049 BC) who declared himself as the king and God of "Ur" city after the reign of Naram Sin.

Predicted to have lived between 638 and $55^{8} \mathrm{BC}$, Solon was the first Greek statesman to establish direct democracy in the real sense. The Greek Democracy which continued its development later with the reforms made by Cleisthenes (508/7 BC) and Efialtes (462 BC) reached its top level under the reign of Pericles (495-429 BC). 
religion are one and are represented by the same person, a person is bound to the state through slavery. In this system, the state has absolute power over the society and land over which he has sovereignty. As for Greek democracies, they share power with the citizens and allow everyone to participate in governance. The previous experiences show that it caused problems in such crises as war and famine, and citizens competed in order to increase their power and opportunities, preventing the sus-

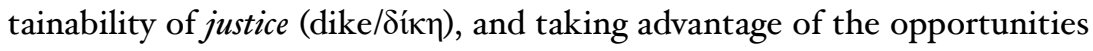
of fractionising. Therefore, stressing in Crito that citizens have duties against their state and community, he develops a contract understanding in which citizens and the state belong to one another. Thanks to this, on the one hand, citizens are rescued from slavery like in sacred kingdoms; on the other hand, he designs a political system which prevents citizens from following their passions, lusts and ambitions free of their duties. Indeed, this approach prevents the expansion of public life so that it does not contain private life on the one side, and also prevents private life from ruining the corner stones which make the public life sustainable on the other side. Moreover, in Crito, there is also one of the most important discursive transformations in the history of political philosophy. In this dialogue, Socrates proposes a new perspective on law and duties and the belonging of citizens, not because they are functional compared to those in other political systems, but simply because they are right. In this way, a political discourse that searches not only for a functional regime but also a "right" and "just" regime should be used in order to achieve accomplishment.

\section{References}

Aristotle (1959). Politics. (Trans. H. Rackham). London: William Heinemann Ltd.

Huard, R. (2007). Plato's Political Philosophy: The Cave. New York: Algora Publishing.

Likhovski, A. (1997). "Tyranny" in Nineteenth-Century American Legal Discourse: A Rhetorical Analysis. The fournal of Interdisciplinary History, 28 (2), 205-223.

Logan, M. (1978). Rhetorical Analysis: Towards a Tropology of Reading. New Literary History, 9 (3), 619-625. 
Plato (1997). Complete Works. (Ed. J. M. Cooper). Indianapolis: Hackett Publishing Company.

Russell, D. C. (2005). Plato on Pleasure and the Good Life. New York: Oxford University Press.

Weiss, R. (1998). Socrates Dissatisfied: An Analysis of Plato's 'Crito'. New York \& Oxford: Oxford University Press.

Öz: Bu çalıșmada Platon'un Kriton adlı eseri retorik analizi yöntemiyle analiz edilir. Platon'un Kriton adlı eseri politika felsefesinin "kanon”u arasında yer alan en önemli eserlerden biridir. Bu eserinde Platon, kendi politika felsefesinin bașlıca niteliklerini geliștirir. Sokrates'in her zaman bağlı kaldığı ahlaki prensipleri zayıflatmamak için, mahkûm olduğu idam cezasından kaçmamayı tercih etmesinden ilham alan Platon, ödev, yurttaşlık ve adalet kavramlarını ele alır. Bu sayede ideal bir "polis"in ve yurttaşın hangi niteliklere sahip olmaları gerektiğine dair felsefi kavrayıșını geliștirir. Platon'un tüm felsefe tarihi üzerindeki etkisi ve belirleyiciliği dikkate alındığında, Kriton'un yeni analiz metotlarıla yeniden değerlendirilmesi zaruret arz etmektedir. Bu anlamda, Platon'un idealize ettiği bir devleti tesis etmek amacıyla eserlerini biçimlendirdiği dikkate alınacak olursa, yazarın amaçlarından hareketle inceleme nesnesini ele alan retorik analizi metoduyla Kriton'un incelenmesi önemlidir.

Anahtar Kelimeler: Kriton, polis, ödev, yurttașlık, doğruluk.

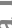




\section{$\mathrm{IO} 2$}

业 